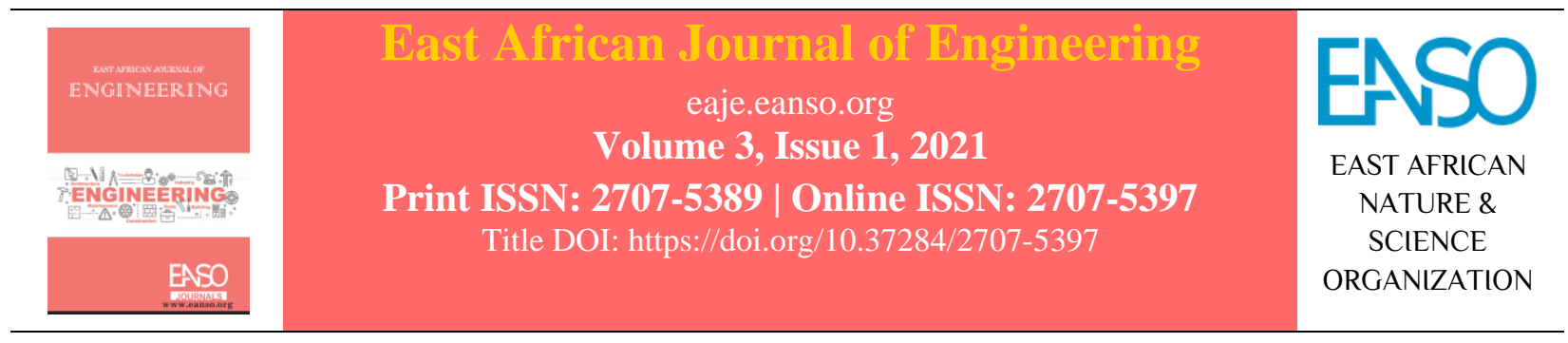

Original Article

\title{
Kenyan Government Involvement on BIM and its Effect on BIM Adoption amongst Building Contractors.
}

\author{
Joel Odhiambo Oyuga ${ }^{{ }^{*}}$, Dr Abednego Gwaya, PhD ${ }^{2}$ \& Prof. Mugwima Njuguna, PhD \\ ${ }^{1}$ The Technical University of Kenya, P. O. Box 52428 - 00200, Nairobi, Kenya. \\ ${ }^{2}$ Jomo Kenyatta University of Agriculture and Technology, P. O. Box 62000 - 00200, Nairobi, Kenya. \\ * Author for Correspondence ORCID ID: https://orcid.org/0000-0002-9729-6033; Email: joel.oyuga@ tukenya.ac.ke.
}

Article DOI: https://doi.org/10.37284/eaje.3.1.414

\section{Publication Date: ABSTRACT}

16 September 2021 Building Information Modelling (BIM) has been touted as a new outstanding technology and governments who have noticed this is getting involved. This study

Keywords: investigated the current level of the Kenyan Government's involvement and how this has influenced adoption amongst building contractors. This study also

BIM, compares global trends in the context to Kenya. This study identified roles like BIM Mandates, initiation and regulation that governments could undertake to encourage adoption. BIM Policies, A random sampling of registered contractors with active construction sites within BIM Policies, Nairobi County was used to identify respondents. Using a one-sample t-test with BIM Regulations, a universal mean of 2 representing weak government involvement, with $\mathrm{t}(61)=$ Building $2.39, \alpha>0.05, \mathrm{M}=2.05$ and $\mathrm{S}=1.53$, the Kenyan government's involvement in Information BIM and its performance on the roles was weak. There was no relationship Modelling. between the government roles and BIM except for BIM Initiation which had a weak positive relationship. This study makes recommendations like the creation of a legal BIM mandate and the establishment of a BIM implementation body This is the first in-depth study in Kenya that critically looks at the government's role on issues relating to BIM amongst Building contractors and gives precedence for subsequent comparative studies locally or regionally.

\section{APA CITATION}

Oyuga, J. O., Gwaya, A., \& Njuguna, M. (2021). Kenyan Government Involvement on BIM and its Effect on BIM Adoption amongst Building Contractors East African Journal of Engineering, 3(1), 99-113. https://doi.org/10.37284/eaje.3.1.414

\section{CHICAGO CITATION}

Oyuga, Joel Odhiambo, Abednego Gwaya, \& Mugwima Njuguna. 2021. "Kenyan Government Involvement on BIM and its Effect on BIM Adoption amongst Building Contractors". East African Journal of Engineering 3 (1), 99-113. https://doi.org/10.37284/eaje.3.1.414.

\section{HARVARD CITATION}

Oyuga, J. O., Gwaya, A., and Njuguna, M. (2021) "Kenyan Government Involvement on BIM and its Effect on BIM Adoption amongst Building Contractors", East African Journal of Engineering, 3(1), pp. 99-113. doi: 10.37284/eaje.3.1.414.

99 | This work is licensed under a Creative Commons Attribution 4.0 International License. 


\section{IEEE CITATION}

J. O., Oyuga., A. Gwaya., \& Njuguna, M. "Kenyan Government Involvement on BIM and its Effect on BIM Adoption amongst Building Contractors," EAJE, vol. 3, no. 1, pp.99-113, Sep. 2021.

\section{MLA CITATION}

Oyuga, Joel Odhiambo, Abednego Gwaya, \& Mugwima Njuguna. "Kenyan Government Involvement on BIM and its Effect on BIM Adoption amongst Building Contractors." East African Journal of Engineering, Vol. 3, no. 1, Sep. 2021, pp. 99-113, doi:10.37284/eaje.3.1.414.

\section{INTRODUCTION}

\section{Background Information}

Construction is a critical sector of development in any economy. In Kenya, the sector's GDP contribution in 2019, before disruptions by the COVID-19 pandemic, was valued at $\$ 5.2 \mathrm{~B}$, which was $5.6 \%$ of the economy (KNBS, 2020, p. 27). When secondary contributors like mining and manufacturing to the construction industry are included, the overall contribution was $8.5 \%$. Despite this contribution, this sector experiences several challenges with the outstanding one being the low absorption of development expenditure for construction in the public sector (KPBO, 2020, p. 18) due to the inability to streamline the industry. This is due to the diverse client tastes, diverse actors, different delivery methods (Alhusban et al., 2017, p. 109), different deliverables (Enynon, 2016, p. 113), diverse workflow processes (Arayici, 2015, p. 72), and different tools. A combination of diversity of these attributes bogs down the construction process making it inefficient (Gwaya, 2016, p. 30). Building Information Modelling (BIM) has been touted as an efficient manager to these diversities.

BIM is a concept around virtual modelling and construction of assets like infrastructure and buildings during which relevant information is embedded into the virtual model throughout its lifecycle (Enynon, 2016, p. 3). This process enables the consolidation of various capabilities generated by the various actors, delivery methods, deliverables, and workflow processes into few seamless BIM tools. Examples of these capabilities are 3D parametric modelling, 4D modelling, 5D modelling, Integrated Design Coordination, Interoperability and Clash Detection, Structural Analysis, and Modelling.

While there has been a notable growth of BIM adoption in jurisdictions like Chile, Singapore, UK, and USA, this has not been reflected within the Kenyan Construction Industry whose adoption rate is still low (Manza, 2016, p. 18). The main objective of this study, therefore, is to establish the level of Kenyan Government involvement on BIM issues amongst Building contractors by assessing the level of performance on key indicators associated with government involvement in BIM. This study aims at establishing various strategies that would assist the Government of Kenya to start planning and prioritizing for BIM adoption.

\section{To Govern or Not to Govern?}

BIM offers digital modelling, data embedding and collecting technologies that aid to integrate design, analysis, simulation, construction, maintenance and decommissioning (Furneaux \& Kivvits, 2008, p. 6). This BIM process is critical to governments since it helps amongst other things, in creating a detailed national database of public and private assets. These databases help governments in making critical decisions like planning, budgeting, and life-cycling public assets.

While it is agreeable amongst most BIM researchers that globally, the level of BIM awareness is high (James et al., 2016, p. 10), the level of BIM adoption varies. Table 1 compares the level of government involvement and BIM adoption levels in various jurisdictions as of June 2019. While several factors may be causing the varying levels of BIM adoption, there is a strong correlation between government 
involvement on issues of BIM and the level of BIM

adoption in the said jurisdiction.

Table 1: Levels of BIM Adoption in various jurisdictions (Source-Author)

\begin{tabular}{|c|c|c|c|c|c|}
\hline Country & $\begin{array}{l}\text { Percentage } \\
\text { of BIM } \\
\text { Adoption }\end{array}$ & $\begin{array}{l}\text { Year in } \\
\text { question }\end{array}$ & $\begin{array}{l}\text { Is the } \\
\text { governmen } \\
\text { t involved? }\end{array}$ & If yes, how & Source \\
\hline Chile & $53 \%$ & 2016 & $\mathrm{NO}$ & $\mathrm{n} / \mathrm{a}$ & $\begin{array}{l}\text { (Loyola \& } \\
\text { López, 2018, p. } \\
\text { 3) }\end{array}$ \\
\hline France & $38 \%$ & 2017 & NO & $\mathrm{n} / \mathrm{a}$ & $\begin{array}{l}\text { (ECSO, 2019, } \\
\text { p. 9) }\end{array}$ \\
\hline Germany & $25 \%$ & 2018 & NO & $\mathrm{n} / \mathrm{a}$ & $\begin{array}{l}\text { (WEF \& BCG, } \\
2018, \text { p. 6) }\end{array}$ \\
\hline Singapore & $80 \%$ & 2015 & YES & $\begin{array}{l}\text { Mandates, Policy generator, } \\
\text { Funder }\end{array}$ & $\begin{array}{l}\text { (Zakaria et al., } \\
\text { 2013, p. 3) }\end{array}$ \\
\hline UK & $73 \%$ & 2019 & YES & $\begin{array}{l}\text { Mandates, Policy generator, } \\
\text { Funder, Researcher }\end{array}$ & $\begin{array}{l}\text { (NBS, 2019, p. } \\
\text { 9) }\end{array}$ \\
\hline USA & $79 \%$ & 2013 & YES & $\begin{array}{l}\text { Policy generator, Funder, } \\
\text { Researcher }\end{array}$ & $\begin{array}{l}\text { (Cheng \& Lu, } \\
\text { 2015, p. 4) }\end{array}$ \\
\hline
\end{tabular}

Most governments have taken note of this correlation and have started getting involved on issues of BIM. Chile is fast-tracking its mandate by making BIM mandatory in all public projects by 2020 (Loyola \& López, 2018, p. 3), Germany had also put in place a mandate to implement level 1 BIM from 2010 (Galić et al., 2017, p. 7). In France, though the government has deliberately avoided imposing a mandate, it is using its policies in the housing industry to improve BIM uptake (European Construction Sector Observatory, 2019, p. 9).

\section{THEORIES OF TECHNOLOGY ADOPTION}

This study limited itself to Diffusion of Innovation Theory and Hype-Cycle Theory with a specific aim of understanding how government involvement influences adoption rates.

\section{Diffusion of Innovation and Government Involvement.}

This theory was pioneered by Peter Schumpeter in 1912 where he showed a linear progression on the spread of technology (Sarkar, 1998, p. 1). Diffusion is a mechanism that spreads new products and processes (products hereafter) in an economy, thereby displacing existing products. Where a product is not free, potential adopters will gauge the cost incurred and benefits accrued. Where benefits exceed the cost, successful innovation will have taken place (Rogers, 1983, p. 11) and adoption will be easy. In such a situation, the government gets involved as a regulator to ensure that products to be released shall be helpful and not harmful. Where cost exceeds benefits, successful innovation will not have taken place and adoption would be difficult. Where the government sees a long-term benefit of the product despite the high-cost low benefit, it intervenes as a mandator and compels the public to adopt it. The success of diffusion relies on the need for information about the product to be communicated (Chang, 2010, p. 2) and spread as far and fast as possible.

Where the innovation is successful, product information is effortlessly spread through contagion and influence from peers and the government does not need to get involved. Where the innovation is not successful, the government gets involved in influencing communication as a broadcaster and 
demonstrator. The success of innovation relies on a short timeline between innovation dissemination and adoption. Where the innovation is successful, adoption time for the product is short and the government does not need to get involved. Where the innovation is not successful, the adoption time may get longer, and the government may intervene as a policy maker and impose time deadlines for the adoption of the product.

\section{Hype-Cycle and Government Involvement}

This theory was pioneered by Gartner Research Inc in 1995 and it characterizes the typical progression of an emerging technology from over-enthusiasm through a period of disillusionment to an eventual understanding of the technology's relevance and role in its market (Fenn \& Linden, 2003, p. 5). Hype-cycle is a mechanism that spreads new products in an economy through strong publicity using mass media and communication interfaces. During the technology trigger phase, on the rising phase and at the peak phase (Zainon et al., 2011, p. 5), the innovators do a lot of marketing for their product. Where the government does not have a direct interest in the product, it comes in as a regulator. Where it is an interested party, the government comes in as an initiator/driver, adopter, funder, broadcaster and demonstrator, and researcher. During the trough of disillusionment phase when adopters leave the product in droves (Muñoz-Saavedra et al., 2020, p. 5), where the government is not an interested party, it just watches the near-collapse of the product. Where the government is an interested party, it intervenes as a mandator to compel adopters to continue using it. During the slope of enlightenment stage when the innovators refine their second-generation product (Lajoie \& Bridges, 2014, p. 2), where the government has no interest it refines its regulations and policies to prevent the previous experience again. Where the government is an interested party, its involvement as a funder and researcher is enhanced to ensure that the product is refined.

\section{ROLES OF GOVERNMENT IN BIM ADOPTION AND CONCEPTUAL FRAMEWORK}

Based on the discussions of theories above, the government comes out as a major player in influencing BIM adoption.

\section{Government as a BIM Initiator, Driver and Demonstrator}

Governments as the biggest consumers (Al-abri et al., 2018, p. 5) have the potential of becoming chief adopters of BIM technologies within its jurisdiction. Where the government needs to internally design and execute various economic and infrastructural projects and therefore has a department of Public Works (Musa et al., 2018, p. 3), BIM adoption tends to go up because of the mass adoption by government entities. Most governments whose countries have a high BIM adoption take advantage of this to showcase the technology by broadcasting and demonstrating its capabilities to the public in a bid to convince the public to join them in using the BIM tool. Various governments have started generating localized BIM templates to be used within their jurisdiction (CIBSE \& TUD, 2020, p. 56), generating BIM training guides (BCA, 2013, p. 5 ), sponsoring of BIM seminars and bootcamps (Pal \& Nassarudin, 2020, p. 5) and availing BIM laboratories (Maharika et al., 2020, p. 25).

\section{Government as a BIM Mandator}

Where there is a need to intervene on the level of BIM adoption, the government can use legal instruments/mandates (Cao \& Chen, 2018, p. 1) to make it compulsory to adopt BIM. The UK government has come out as a global leader in the digital transformation of the construction industry (NBS, 2019, p. 6) due to the imposition of the BIM Level 2 mandate in the UK in 2016. 


\section{Government as a BIM Regulator}

Where the government externally and indirectly uses BIM technologies as a Project Client, it comes in as a strong regulator by imposing minimum requirements of using BIM in their projects for potential service providers to conform (Eadie et al., 2015 , p. 1) if at all they want to do business with the government. The General Services Administration (GSA hereafter) of the US government is outstanding on this. Though there is no existing BIM mandate in the USA, GSA imposed a regulation in 2007 that all public projects must be done in BIM (Tse, 2009, p. 63).

\section{Government as a BIM Funder}

To accelerate the rate of BIM adoption, governments may fund various facets of BIM activities. Singapore (Tahrani et al., 2015, p. 5) and UK (Arayici, 2015, p. 214) are outstanding when it comes to funding of the mandated bodies, while UK is outstanding on research funding of BIM(Underwood \& Ayoade, 2015, p. 12) and Singapore is outstanding in the funding of BIM training (Kalfa, 2018, p. 6)

\section{Government as Policy Generator}

To guide certain aspects and standards in terms of methodology and deliverables for BIM, the government creates certain policies for this. Examples of such policies include the creation of template files (NBS, 2017, p. 33), open BIM and interoperability (McAuley et al., 2017), eBIM permits (Tse, 2009, p. 63), and BIM software certification (NIBS \& buildingSMART 2012, p. $628)$.

\section{Government as a Task Group Creator}

When certain policies generated as discussed above need attention to ensure proper implementation of the said specific policies, then time-limited task groups are normally created to assist in this (NBS, 2017, p. 28). Examples of such task groups include the EU BIM Task group formed in 2016 for 2 years whose task was to gather collective experience of BIM stakeholders within the EU zone with an aim of understanding various aspects of BIM; like what each country has already done on issues of BIM, what benefits have been accrued from these actions and generate a common EU definition of BIM (EUBIM Task Group, 2016, p. 4). Another example is the Bew-led UK BIM Task group formed in 2012 with a task of delivering BIM and soft landings in the UK public sector by 2016 (Enynon, 2016, p. 20). 


\section{Conceptual Framework}

Figure 1: Conceptual Framework

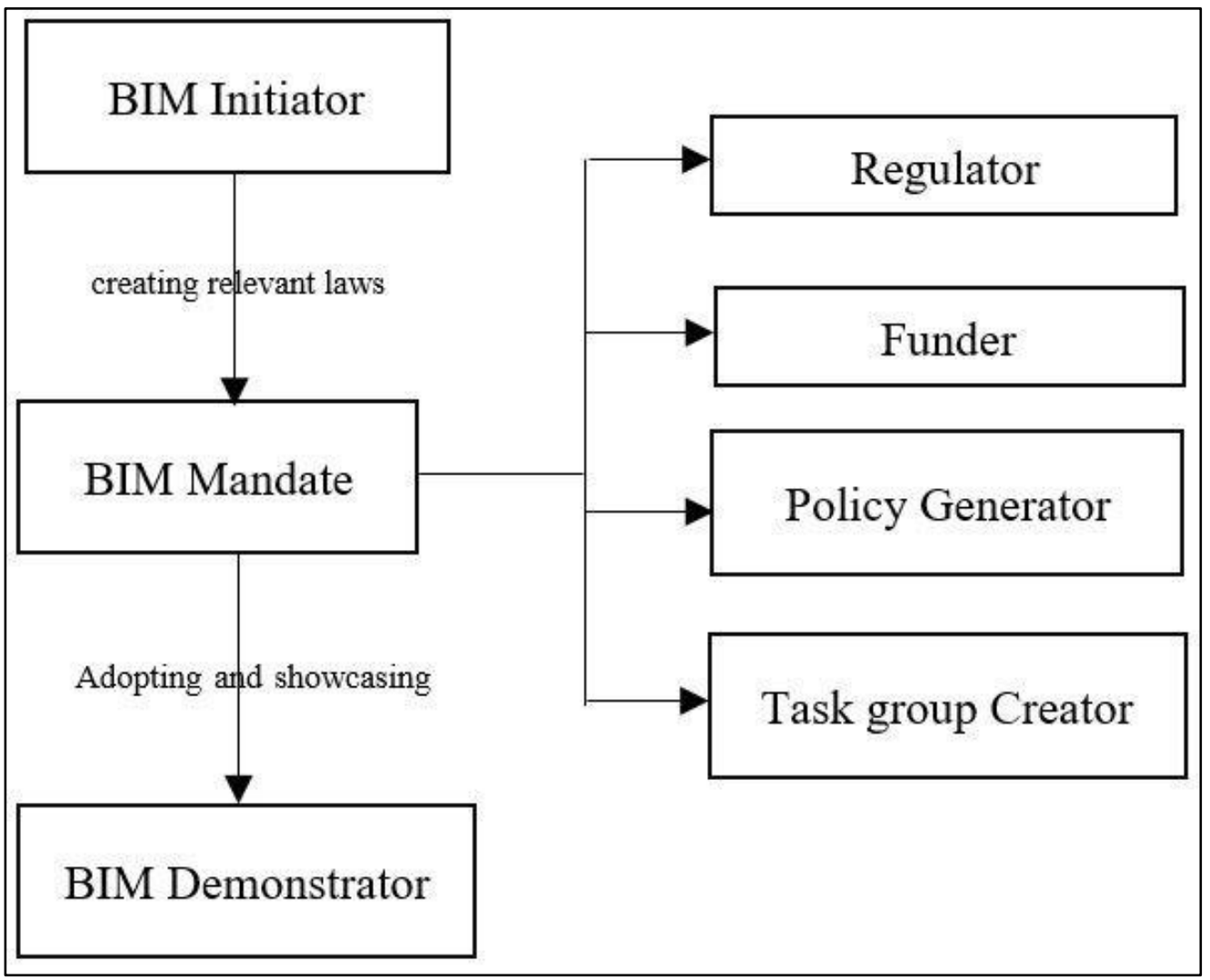

To understand government involvement on BIM issues, this study investigated the current state of roles of government in BIM as discussed. Figure 1 is the conceptual framework showing how these roles may relate to influencing the level of government involvement on BIM with an aim of influencing BIM adoption.

\section{RESEARCH METHODOLOGY}

This study uses a survey method incorporating questionnaires for Building contractors and structured interviews for statutory bodies in Kenya. With the population of National Construction Authority (NCA) Class 4 and above registered building contractors being 1665 , the sample size was 95. Questionnaires were manually administered in 95 active construction sites within Nairobi. The respondents were a member of staff with an executive role in the said organisation. A five-point Likert scale was used to test opinions of Building contractors on various parameters. SPSS was used to analyse the data.

\section{Data Analysis}

\section{Data Reliability and Demographics of Responsive Respondents}

The Cronbach's alpha achieved indicated a high level of data reliability (20 items: $\alpha=0.93$ ). 62 out of 95 responded giving a response rate of $65.26 \%$. Demographics of respondents were diverse with the predominant age being between 41 to 45 , practice experience between 11 to 15 years, and have used BIM in less than 5 projects. The normality tests showed that age, years of practice, and years of using BIM were normally distributed while projects done were non-normally distributed.

104 | This work is licensed under a Creative Commons Attribution 4.0 International License. 


\section{SURVEY RESULTS}

\section{Relationship between Government as an Initiator and BIM Adoption}

The first secondary task of this study was to investigate the relationship between the Government as an initiator, driver, and broadcaster of BIM and BIM Adoption levels amongst Main Contractors. The null hypothesis $\left(\mathrm{H}_{\mathrm{o}}\right)$ stated that the participation of the government in BIM as an initiator, driver, and broadcaster was low, while the alternate hypothesis $\left(\mathrm{H}_{\mathrm{a}}\right)$ stated that participation levels were either too low, moderate, high, or too high. The government initiation score was generated using the average score of government generation of localized BIM templates, government generation of BIM training guides, government sponsoring of BIM specialized CPD seminars and bootcamps, and government availing of BIM laboratories. Using one-sample t-test with $\mathrm{t}(61)=$ $0.617, \alpha>0.05, \mathrm{M}=2.13, \mathrm{SD}=1.61$ (see Table 8), our survey is not significantly different from the null hypothesis.

Table 2: One sample t-test result for "Government as a BIM Initiator" score.

\begin{tabular}{|c|c|c|c|c|c|c|c|}
\hline & \multicolumn{4}{|c|}{ One-Sample Statistics } & \multirow{2}{*}{\multicolumn{3}{|c|}{$\begin{array}{l}\text { One-Sample Test } \\
\text { Test Value }=2\end{array}$}} \\
\hline & & & & & & & \\
\hline & $\mathbf{N}$ & Mean & Std. Dev. & Std. Err. & df & Sig. & $\begin{array}{l}\text { Mean } \\
\text { Diff. }\end{array}$ \\
\hline $\begin{array}{l}\text { Localised BIM standard } \\
\text { templates and data formats }\end{array}$ & 62 & 2.13 & 1.769 & .225 & $.574 \quad 61$ & .568 & .129 \\
\hline BIM training guides and codes & 62 & 2.48 & 1.897 & .241 & $2.009 \quad 61$ & .049 & .484 \\
\hline BIM specialised CPD seminars & 62 & 2.19 & 1.763 & .224 & $.864 \quad 61$ & .391 & .194 \\
\hline Short term boot camps & 62 & 1.92 & 1.540 & .196 & $-.412 \quad 61$ & .681 & -.081 \\
\hline $\begin{array}{l}\text { Institutional based } \\
\text { laboratories }\end{array}$ & 62 & 1.90 & 1.647 & .209 & $-.463 \quad 61$ & .645 & -.097 \\
\hline
\end{tabular}

Narrowing down to individual indicators as shown in Table 2, government involvement in generating localized BIM templates with $\mathrm{t}(61)=0.574, \alpha>$ $0.05, \mathrm{M}=2.13, \mathrm{SD}=1.77$; government initiated BIM specialized CPD seminars with $\mathrm{t}(61)=0.864$, $\alpha>0.05, \mathrm{M}=2.19, \mathrm{SD}=1.76$; government sponsoring short term bootcamps with $\mathrm{t}(61)=$ $0.412, \alpha>0.05, \mathrm{M}=1.92, \mathrm{SD}=1.54$ and government initiated Institutional based BIM laboratories with $\mathrm{t}(61)=-0.463, \alpha>0.05, \mathrm{M}=1.90$, $\mathrm{SD}=1.65$ were not significantly different from the null hypothesis. Government Initiated BIM training guides and codes with $\mathrm{t}(61)=2.00, \alpha<0.05, \mathrm{M}=$
2.48, $\mathrm{SD}=1.90$ was significantly different from the null hypothesis since the score was moderate.

On the Pearson Relationship between the government as an initiator and BIM adoption, with $\mathrm{p}<0.05$, as shown in Table 3, these variables had a weak positive correlation. A one-way ANOVA test was done with the null hypothesis $\left(\mathrm{H}_{\mathrm{o}}\right)$ stating that variances were equal amongst the indicators tested while the alternate hypothesis $\left(\mathrm{H}_{\mathrm{a})}\right.$ stating that these variances were not equal amongst the indicators that generate the scores. The ANOVA summary in Table 4 below indicates that with $\mathrm{p}<0.05$, the null hypothesis was rejected and 52\% of BIM adoption

105 | This work is licensed under a Creative Commons Attribution 4.0 International License. 
was explained by the role played by the government as an initiator, and variance between the various groups was 5 times greater than variances within the groups. These two results showed a weak relationship between these two variables causing us to do a bivariate regression model.

Table 3: Correlation between "Government as an Initiator" Score and BIM Adoption

\begin{tabular}{|c|c|c|c|}
\hline \multicolumn{4}{|l|}{ Correlations } \\
\hline & & $\begin{array}{l}\text { Government as a BIM } \\
\text { Initiator Score }\end{array}$ & $\begin{array}{l}\text { Overall BIM } \\
\text { Adoption Score }\end{array}$ \\
\hline $\begin{array}{l}\text { Government as a BIM } \\
\text { Initiator Score }\end{array}$ & $\begin{array}{l}\text { Pearson Correlation } \\
\text { Sig. (2-tailed) } \\
\text { N }\end{array}$ & 1 & $\begin{array}{l}.287^{*} \\
.024 \\
62\end{array}$ \\
\hline
\end{tabular}

*. Correlation is significant at the 0.05 level (2-tailed).

Table 4: One-way ANOVA Test between "Government as an Initiator" Score and BIM Adoption

\begin{tabular}{|c|c|c|c|c|c|c|}
\hline \multicolumn{7}{|l|}{ Tests of Between-Subjects Effects } \\
\hline \multicolumn{7}{|c|}{ Dependent Variable: Overall BIM Adoption Score } \\
\hline Source & $\begin{array}{l}\text { Type III Sum } \\
\text { of Squares }\end{array}$ & df & $\begin{array}{l}\text { Mean } \\
\text { Square }\end{array}$ & $\mathbf{F}$ & Sig. & $\begin{array}{l}\text { Partial Eta } \\
\text { Squared }\end{array}$ \\
\hline Corrected Model & $69.384^{\mathrm{a}}$ & 11 & 6.308 & 4.991 & .00 & .523 \\
\hline Intercept & 115.962 & 1 & 115.962 & 91.749 & .00 & 647 \\
\hline $\begin{array}{l}\text { Government as a BIM Initiator } \\
\text { Score }\end{array}$ & 69.384 & 11 & 6.308 & 4.991 & .00 & .523 \\
\hline Error & 63.195 & 50 & 1.264 & & & \\
\hline Total & 375.109 & 62 & & & & \\
\hline Corrected Total & 132.579 & 61 & & & & \\
\hline
\end{tabular}

a. $R$ Squared $=.523$ (Adjusted $R$ Squared $=.418$ )

For the bivariate model, with a null hypothesis $\left(\mathrm{H}_{\mathrm{o}}\right)$ stating that none of the coefficients in the "Government as an Initiator" score predict BIM adoption with the alternate hypothesis $\left(\mathrm{H}_{\mathrm{a}}\right)$ stating that most of the coefficients in the "Government as an Initiator" score predict BIM adoption, as shown in Table 5, with sig $(\mathrm{p})<0.05$, the null hypothesis was rejected with the regression equation for this relationship stating that:

BIM Adoption Score $=0.263 \mathrm{x}$ "Government as a BIM initiator" Score +1.418

Table 5: Bivariate Regression Model between "Government as an Initiator" Score and BIM Adoption

\begin{tabular}{|c|c|c|c|c|c|}
\hline \multicolumn{6}{|l|}{ Coefficients $^{\mathrm{a}}$} \\
\hline \multirow[b]{2}{*}{ Model } & \multicolumn{2}{|c|}{$\begin{array}{l}\text { Unstandardized } \\
\text { Coefficients }\end{array}$} & \multirow{2}{*}{$\begin{array}{l}\text { Standardized } \\
\text { Coefficients } \\
\text { Beta }\end{array}$} & \multirow[t]{2}{*}{$\mathbf{t}$} & \multirow[t]{2}{*}{ Sig. } \\
\hline & $\mathbf{B}$ & Std. Error & & & \\
\hline 1 (Constant) & 1.418 & .302 & & 4.701 & .000 \\
\hline Government as a BIM Initiator Score & .263 & .114 & .287 & 2.321 & .024 \\
\hline
\end{tabular}

106 | This work is licensed under a Creative Commons Attribution 4.0 International License. 


\section{Relationship between Government as a Mandator and BIM Adoption}

The second secondary task of this study was to investigate the relationship between the Government as mandator and BIM Adoption levels amongst Main Contractors. The null hypothesis $\left(\mathrm{H}_{\mathrm{o}}\right)$ stated that the participation of the government in BIM as a mandator was low, while the alternate hypothesis $\left(\mathrm{H}_{\mathrm{a}}\right)$ stated that participation levels were either too low, moderate, high, or too high. Using one-sample t-test with $\mathrm{t}(61)=-0.764, \alpha>0.05, \mathrm{M}$ $=1.84, \mathrm{SD}=1.66$ (see Table 8), our survey is not significantly different from the null hypothesis.

On the Pearson Relationship between the government as a mandator and BIM adoption, as shown in Table 9, with $\mathrm{p}>0.05$, these variables were not significantly correlated thereby eliminating the need of doing the one-way ANOVA test and generating the bivariate relationship.

\section{Relationship between Government as a Regulator and BIM Adoption}

The third secondary task of this study was to investigate the relationship between the Government as regulator and BIM Adoption levels amongst Main Contractors. The null hypothesis $\left(\mathrm{H}_{\mathrm{o}}\right)$ stated that the participation of the government in BIM as a regulator was low, while the alternate hypothesis $\left(\mathrm{H}_{\mathrm{a}}\right)$ stated that participation levels were either too low, moderate, high, or too high. Using one-sample t-test with $\mathrm{t}(61)=-0.574, \alpha>0.05, \mathrm{M}$ $=1.87, \mathrm{SD}=1.77$ (see Table 8 ), our survey is not significantly different from the null hypothesis.

On the Pearson Relationship between the government as a regulator and BIM adoption, as shown in Table 9, with $\mathrm{p}>0.05$, these variables were not significantly correlated thereby eliminating the need of doing the one-way ANOVA test and generating the bivariate relationship.

\section{Relationship between Government as a BIM Funder and BIM Adoption}

The fourth secondary task of this study was to investigate the relationship between the Government as BIM funder and BIM Adoption levels amongst Main Contractors. The null hypothesis $\left(\mathrm{H}_{\mathrm{o}}\right)$ stated that the government funding of BIM activities was low, while the alternate hypothesis $\left(\mathrm{H}_{\mathrm{a}}\right)$ stated that participation levels were either too low, moderate, high, or too high. Using one-sample t-test with $\mathrm{t}(61)=0, \alpha>0.05, \mathrm{M}=2.00$, $\mathrm{SD}=1.70$ (see Table 8), our survey is not significantly different from the null hypothesis.

On the Pearson Relationship between the government as a BIM funder and BIM adoption, as shown in Table 9, with $\mathrm{p}>0.05$, these variables were not significantly correlated thereby eliminating the need of doing the one-way ANOVA test and generating the bivariate relationship.

\section{Relationship between Government as a BIM Policy Generator and BIM Adoption}

The fifth secondary task of this study was to investigate the relationship between the Government as a BIM policy generator and BIM Adoption levels amongst Main Contractors. The null hypothesis $\left(\mathrm{H}_{\mathrm{o}}\right)$ stated that participation of government on BIM policy generation was low, while the alternate hypothesis $\left(\mathrm{H}_{\mathrm{a}}\right)$ stated that participation levels were either too low, moderate, high, or too high. Government Policy Generation Score was generated using the averages of the indicators namely Interoperability, BIM esubmission, open BIM, and BIM software certification. Using one-sample t-test with $\mathrm{t}(61)=$ $0.904, \alpha>0.05, \mathrm{M}=2.22, \mathrm{SD}=1.90$ (see Table 8), our survey is not significantly different from the null hypothesis.

Narrowing down to individual indicators as shown in Table 6, government policies on BIM interoperability with $\mathrm{t}(61)=0.674, \alpha>0.05, \mathrm{M}=$ $2.16, \mathrm{SD}=1.88$; government policies on e-BIM submission and permits with $\mathrm{t}(61)=0.906, \alpha>0.05$, $\mathrm{M}=2.23, \mathrm{SD}=1.96$; government policy on open 
BIM with $\mathrm{t}(61)=1.09, \alpha>0.05, \mathrm{M}=2.26, \mathrm{SD}=$ 1.96 and government policy on BIM software certification with $\mathrm{t}(61)=0.906, \alpha>0.05, \mathrm{M}=2.23$,
$\mathrm{SD}=1.96$ (see Table 8) were not significantly different from the null hypothesis.

Table 6: One sample t-test result for "Government as a BIM Policy Generator" score

\begin{tabular}{|c|c|c|c|c|c|c|c|c|}
\hline & \multicolumn{4}{|c|}{ One-Sample Statistics } & \multirow{2}{*}{\multicolumn{4}{|c|}{$\begin{array}{l}\text { One-Sample Test } \\
\text { Test Value = } 2\end{array}$}} \\
\hline & \multirow[b]{2}{*}{$\mathbf{N}$} & \multirow[b]{2}{*}{ Mean } & \multirow[b]{2}{*}{ Std. Dev } & \multirow[b]{2}{*}{ Std. Err } & & & & \\
\hline & & & & & $\mathbf{t}$ & df & Sig. & $\begin{array}{l}\text { Mean } \\
\text { Diff }\end{array}$ \\
\hline Interoperability of BIM tools & 62 & 2.16 & 1.883 & .239 & .674 & 61 & .503 & .161 \\
\hline e-Building submission and permits & 62 & 2.23 & 1.962 & .249 & .906 & 61 & .368 & .226 \\
\hline Open BIM & 62 & 2.26 & 1.864 & .237 & 1.090 & 61 & .280 & .258 \\
\hline BIM software certification & 62 & 2.23 & 1.962 & .249 & .906 & 61 & .368 & .226 \\
\hline
\end{tabular}

On the Pearson Relationship between the government as a BIM Policy generator and BIM adoption, as shown in Table 9, with $\mathrm{p}>0.05$, these variables were not significantly correlated thereby eliminating the need of doing the one-way ANOVA test and generating the bivariate relationship.

\section{Relationship between Government as a BIM Task Group Creator and BIM Adoption}

The sixth secondary task of this study was to investigate the relationship between the Government as a BIM task group creator and BIM Adoption levels amongst Main Contractors. The null hypothesis $\left(\mathrm{H}_{0}\right)$ stated that the government creation of BIM task groups was slow, while the alternate hypothesis $\left(\mathrm{H}_{\mathrm{a}}\right)$ stated that creation processes were either too slow, moderate, quick or too quick. Government Task group Score was generated using the averages of the indicators namely creation of BIM-related statutory and professional bodies and creation of BIM specific task group. Using one-sample t-test with $\mathrm{t}(61)=$ $1.138, \alpha>0.05, \mathrm{M}=2.23, \mathrm{SD}=1.56$ (see Table 8), our survey is not significantly different from the null hypothesis.

Narrowing down to individual indicators as shown in Table 7, creation of BIM specific bodies with $\mathrm{t}$ $(61)=0.646, \alpha>0.05, \mathrm{M}=2.13, \mathrm{SD}=1.57$ and BIM specific task groups with $\mathrm{t}(61)=1.333, \alpha>$ $0.05, \mathrm{M}=2.32, \mathrm{SD}=1.91$ were not significantly different from the null hypothesis.

Table 7: One sample t-test result for "Government as a BIM Task group Creator" score

\begin{tabular}{llllllllll}
\hline & \multicolumn{3}{c}{ One-Sample Statistics } & \multicolumn{5}{c}{ One-Sample Test } \\
\cline { 2 - 10 } & & $\mathbf{N}$ & Mean & Std. Dev. & Std. Err. & t & df & Sig. & Mean Diff. \\
\hline $\begin{array}{l}\text { Statutory bodies and } \\
\text { professional organisations }\end{array}$ & 62 & 2.13 & 1.573 & .200 & .646 & 61 & .521 & .129 \\
$\begin{array}{l}\text { Government backed task } \\
\text { groups on BIM }\end{array}$ & 62 & 2.32 & 1.906 & .242 & 1.333 & 61 & .188 & .323 \\
\hline
\end{tabular}

On the Pearson Relationship between the government as a BIM task group creator and BIM adoption, as shown in Table 9, with $\mathrm{p}>0.05$, these variables were not significantly correlated thereby eliminating the need of doing the one-way ANOVA test and generating the bivariate relationship.

108 This work is licensed under a Creative Commons Attribution 4.0 International License. 
Relationship between Government Involvement in BIM and BIM Adoption.

The primary tasks of this study were to investigate the level of government involvement on issues of BIM in Kenya and to see the relationship between this involvement and BIM adoption levels amongst main contractors. The null hypothesis $\left(\mathrm{H}_{\mathrm{o}}\right)$ stated that the government involvement on issues of BIM was low, while the alternate hypothesis $\left(\mathrm{H}_{\mathrm{a}}\right)$ stated that involvement was either too low, moderate, high, or too high. Government Involvement Score was generated using the averages of all the factors discussed above. As shown in Table 8, using onesample t-test with $\mathrm{t}(61)=0.239, \alpha>0.05, \mathrm{M}=2.05$, $\mathrm{SD}=1.53$, our survey is not significantly different from the null hypothesis.

Table 8: One sample t-test result for "Government Involvement in BIM" score and the other factors

\begin{tabular}{|c|c|c|c|c|c|c|c|c|}
\hline & \multirow{2}{*}{\multicolumn{3}{|c|}{ One-Sample Statistics }} & \multirow{2}{*}{\multicolumn{5}{|c|}{$\begin{array}{l}\text { One-Sample Test } \\
\text { Test Value }=2\end{array}$}} \\
\hline & & & & & & & & \\
\hline & $\mathbf{N}$ & Mean & Std. Dev. & Std. Err. & $\mathbf{t}$ & df & Sig. & Mean Diff \\
\hline $\begin{array}{l}\text { "Government Involvement in } \\
\text { BIM" Score }\end{array}$ & 62 & 2.05 & 1.532 & 0.195 & .239 & 61 & .812 & .047 \\
\hline $\begin{array}{l}\text { "Government as a } \text { BIM } \\
\text { Initiator" Score }\end{array}$ & 62 & 2.13 & 1.606 & 0.204 & .617 & 61 & .540 & .126 \\
\hline $\begin{array}{l}\text { "Government as a } \text { BIM } \\
\text { Mandator" Score }\end{array}$ & 62 & 1.84 & 1.661 & 0.211 & -.764 & 61 & .448 & -.161 \\
\hline $\begin{array}{l}\text { "Government as a } \\
\text { Regulator" Score }\end{array}$ & 62 & 1.87 & 1.769 & 0.225 & -.574 & 61 & .568 & -.129 \\
\hline $\begin{array}{l}\text { "Government as a BIM Funder" } \\
\text { Score }\end{array}$ & 62 & 2.00 & 1.699 & 0.216 & 0.000 & 61 & 1.000 & 0.000 \\
\hline $\begin{array}{l}\text { "Government as a BIM Policy } \\
\text { Generator" Score }\end{array}$ & 62 & 2.22 & 1.896 & 0.241 & .904 & 61 & .369 & .218 \\
\hline $\begin{array}{l}\text { "Government as a BIM Task } \\
\text { group Creator" Score }\end{array}$ & 62 & 2.23 & 1.562 & 0.198 & 1.138 & 61 & .259 & .226 \\
\hline
\end{tabular}

On the Pearson Relationship between government involvement in BIM and BIM adoption, as shown in Table 9, with $\mathrm{p}>0.05$, these variables were not significantly correlated thereby eliminating the need of doing the one-way ANOVA test and generating the multivariate relationship

Table 9: Pearson Correlation between roles of Kenyan Government in BIM and BIM Adoption

\begin{tabular}{lll}
\hline Correlations & & \\
\hline Overall BIM Adoption Score & & $\begin{array}{l}\text { Overall Adoption } \\
\text { Score }\end{array}$ \\
& Pearson Correlation & 1 \\
& Sig. (2-tailed) & \\
\hline "Government Involvement in BIM" Score & N & 62 \\
& Pearson Correlation & .167 \\
& Sig. (2-tailed) & .194 \\
\hline
\end{tabular}

109 | This work is licensed under a Creative Commons Attribution 4.0 International License. 
East African Journal of Engineering, Volume 3, Issue 1, 2021

Article DOI: https://doi.org/10.37284/eaje.3.1.414

\begin{tabular}{lll}
\hline Correlations & & \\
\hline & & $\begin{array}{l}\text { Overall Adoption } \\
\text { Score }\end{array}$ \\
\hline "Government as a BIM Initiator" Score & Pearson Correlation & $.287^{*}$ \\
& Sig. (2-tailed) & .024 \\
& $\mathrm{~N}$ & 62 \\
\hline "Government as a BIM Mandator" Score & Pearson Correlation & .160 \\
& Sig. (2-tailed) & .214 \\
& $\mathrm{~N}$ & 62 \\
\hline "Government as a BIM Regulator" Score & Pearson Correlation & .245 \\
& Sig. (2-tailed) & .055 \\
\hline "Government as a BIM Funder" Score & $\mathrm{N}$ & 62 \\
& Pearson Correlation & .133 \\
& Sig. (2-tailed) & .304 \\
\hline "Government as a BIM Policy Generator" Score & $\mathrm{N}$ & 62 \\
& Pearson Correlation & -.001 \\
& Sig. (2-tailed) & .995 \\
\hline Score & $\mathrm{N}$ & 62 \\
\hline
\end{tabular}

*. Correlation is significant at the 0.05 level (2-tailed).

**. Correlation is significant at the 0.01 level (2-tailed).

\section{STATUS OF GOVERNMENT} INVOLVEMENT ON BIM IN KENYA.

The level of BIM Adoption by Building contractors in Kenya is low, compared to global standards which may be explained by low government involvement on BIM-related matters besides other factors. It is good to contextualise how governments function in Kenya to have a proper understanding of this discussion. In 2010, a new constitution was promulgated which devolved construction-related functions to County governments (GOK, 2010, p. 176) thereby creating 48 entities that are supposed to initiate the six roles discussed under the roles of government to enable BIM adoption in their respective jurisdictions.

With regards to the government being a chief BIM initiator, it clearly came out that within the state department for public works and the 47 departments of urban development had no clear rules with regards to BIM adoption by the governments. The level and efficacy of BIM adoption by designers depended on the individual attitude and effort of the officers involved. With regards to BIM mandating, regulating, policy generating, and specific task group creating, the performance of both levels of government was low. Only 4 out of the 47 counties offer e-submission services for construction permits, and they use the lowest level 0 of BIM maturity (Awwad et al., 2020, p. 2) which allows submission of non-parametric pdf files. The National government through NCA also offers esubmission services for compliance certificate before construction and use level 0 of BIM maturity. With regards to the funding of BIM activities, participation of both levels of government is low. There was no budget allocation for BIM-related activities in any of the governments for the fiscal year running from July 2020 to June 2021 . With this situation, building contractors are neither motivated nor compelled to adopt BIM.

\section{RECOMMENDATIONS}

110 This work is licensed under a Creative Commons Attribution 4.0 International License. 
There is a need to urgently establish a statutory body similar to the Hong Kong Institute of BIM (Ho, 2020 , p. 7) in Kenya to handle and coordinate all BIM related activities, from GIS mapping (Zhu et al., 2020, p. 1), to City Information Modelling (Furjani et al., 2020, p. 3) to BIM in Kenya. This body will coordinate the use of relevant instruments like BIM mandates, policies, and regulations within the two levels of government to push BIM maturity from Level 0 to level 3 within 10 years. This body shall be involved in issues of BIM training at the post-secondary level and in actual practice, progressively improve BIM standards, codes, and guides in Kenya.

\section{REFERENCES}

Al-abri, A., Genc, I. H. and Naufal, G. (2018), The Impact of Government Spending on GDP in a Remitting Country, working paper number IZA DP No. 11676, The IZA Institute of Labor Economics, Bonn, July 2018

Alhusban, M., Al bizri, S., Danso-Amoako, M. \& Gaterell, M. (2017), Procurement Route and Building Information Modelling (BIM) Implementation Effect on Sustainable Higher Education Refurbishment Projects in $M$. Dastbaz, C. Gorse \& A. Moncaster (Eds.), Building Information Modelling, Building Performance and Smart Construction (1st ed., pp. 105-112). Cham, Switzerland: Springer International Publishing AG.

Arayici, Y. (2015). Building Information Modelling. London, United Kingdom: Bookboon Publishers.

Awwad, K. A., Shibani, A. \& Ghostin, M. (2021), Exploring the critical success factors influencing BIM level 2 implementation in the UK construction industry: the case of SMEs. International Journal of Construction Management, 39(1), $1-8$.
Building and Construction Authority - Singapore. (2013). Singapore BIM Essential Guide for BIM Adoption in an Organization. Singapore, Singapore: BCA.

Cao, J. \& Chen, C. (2018). Analysis of the Strategy of Government's BIM under the International Comparative Perspective. In Z.Y. Jiang (Ed), 3rd International Forum on Energy, Environment Science and Materials, IFEESM 2017 (250 - 253). Shenzen, China: Atlantis Press

Chang, H. C. (2010). A New Perspective on Twitter Hashtag Use: Diffusion of Innovation Theory, Proceedings of the 73rd ASIS\&T Annual Meeting, ASIST 2010 (1 - 4). Pittsburgh, USA: ASIS Publishers

Cheng, J. C.P. \& Lu, Q. (2015), A Review of the Efforts and Roles of the Public Sector for BIM Adoption Worldwide. Journal of Information Technology in Construction, 20 (2015), 442 478.

Eadie, R., Browne, M., Odeyinka, H., McKeown, C. $\&$ McNiff, S. (2015), A Survey of Current Status of and Perceived Changes Required for BIM Adoption in the UK. Built Environment Project and Asset Management, 5(1), 4 - 21.

Enynon, J. (2016). Construction Manager's BIM Handbook. West Sussex, United Kingdom: John Wiley \& Sons Ltd.

EUBIM Task Group. (2016). Handbook for the Introduction of Building Information Modelling by the European Public Sector. Brussels, Belgium: EUBIM Task Group.

European Construction Sector Observatory. (2019). Building Information Modelling in the EU Construction Sector. Brussels, Belgium

Fenn, J. \& Linden, A. (2003). Understanding Gartner 's Hype Cycles.

111 This work is licensed under a Creative Commons Attribution 4.0 International License. 
Galić, M., Venkrbec, V., Chmelik, F., Feine, I., Pučko, Z. \& Klanšek, U. (2017), Survey of Accomplishments in BIM Implementation in Croatia, the Czech Republic, Germany, and Slovenia. e-GFOS, 8 (15), 23 - 35.

Furneaux, C. \& Kivvits, R. (2008). BIM Implications for Government.

Gwaya, A. O. (2016). Development of a Project Management Evaluation Model for the Construction Industry in Kenya (Doctoral Dissertation). Jomo Kenyatta University of Agriculture and Technology, Nairobi., Kenya.

Ho, H. H. (2019). BIM Standards in Hong Kong: Development, Impact and Future, 7th Annual International Conference on Architecture and Civil Engineering (ACE 2019) (519 - 527). Singapore, Singapore: TIIKM

James, A. J., Lesado, A., Chalya, G. \& Malson, M. (2016), An Appraisal of the Benefits of Building Information Modelling (BIM) in Architecture. Journal of Applied Sciences \& Environmental Sustainability, 2 (5), 126 - 137.

Kalfa, S. M. (2018), Building Information Modeling (BIM) Systems and their Applications in Turkey. Journal of Construction Engineering, Management \& Innovation, 1 (1), 55 - 66.

Kenya National Bureau of Statistics. (2020). Economic Survey 2020.

Kenya Parliamentary Budget Office. (2020). Unpacking the Estimates of Revenue and Expenditure for 2020/2021 and the Medium Term.

Lajoie, E. W. \& Bridges, L. (2014), Innovation Decisions: Using the Gartner Hype Cycle. Library Leadership \& Management, 28 (4), 1 7.

Loyola, M. \& López, F. (2018), An Evaluation of the Macro-scale Adoption of Building
Information Modeling in Chile: 2013-2016. Journal of Construction, 17 (1), 158 - 171.

Maharika, I. F., Irsan, A., Al Athas, S. I., Susanto, A., Abma, V. \& Yuriandala, Y. (2020), Building Information Modelling (BIM) Adoption Model for Architectural Education. Journal of Design and Built Environment, 20 (3), 22 - 42.

Manza, D. K. (2016). Influence of Building Information Modelling Adoption on Completion of Construction Projects: A Case of Nairobi County (Master's Thesis). University of Nairobi, Nairobi., Kenya.

McAuley, B., Behan, A., McCormack, P., Hamilton, A., Rebelo, E. \& Lynch, S. (2020), Improving the sustainability of the built environment by upskilling SMEs in Building Information Modelling through the Horizon 2020 BIMcert Project. SDAR Journal, 10 (1), 49 -55 .

McAuley, B., Hore, A. \& West, R. (2017). BICP Global BIM Study - Lessons for Ireland's BIM Programme.

Muñoz-Saavedra, L., Miró-Amarante, L., \& Domínguez-Morales, M. (2020), Augmented and virtual reality evolution and future tendency. Applied Sciences (Switzerland), 10 (1), 1 - 23.

Musa, S., Marshall-Ponting, A., Nifa, F. A. A. \& Shahron, S. A. (2018). Building Information Modelling (BIM) in Malaysian Construction Industry: Benefits and Future Challenges. In F. A. A. Nifa, Chong K. L. \& Azham H. (Eds), Proceedings of the 3rd International Conference on Applied Science and Technology (ICAST'18) $(1-10)$. Penang, Malaysia: AIP Publishing

National Building Specifications. (2017). National BIM Report 2017.

National Building Specifications. (2019). National BIM Report 2019.

112 This work is licensed under a Creative Commons Attribution 4.0 International License. 
National Council for Law Reporting. (2010). The Constitution of Kenya 2010.

National Institute of Building Sciences \& buildingSMART alliance. (2012). National BIM Standard - United States TM Version 2.

Pal, A. \& Nassarudin, A. (2020). Integrated Project Delivery Adoption Framework for Construction Projects in India. In I. D. Tommelein \& E. Daniel (Eds), Proceedings of the 28th Annual Conference of the International Group for Lean Construction (IGLC28) (337 - 348). Berkeley, USA: IGLC

Rogers, E. M. (1983). Diffusion of Innovations. New York, USA: The Free Press.

Sarkar, J. (1998), Technological Diffusion: Alternative Theories and Historical Evidence. Journal of Economic Surveys, 12 (2), 131 - 176.

Tahrani, S., Poirier, E. A., Aksenova, G. \& Forgues, D. (2015). Structuring the Adoption and Implementation of BIM and Integrated Approaches to Project Delivery across the Canadian AECO Industry: Key Drivers from Abroad, 11th Construction Specialty Conference $(1-11)$. Vancouver, Canada: CSCE

Tse, T. (2009). The Interoperability of Building Information Models and Document Models in the Hong Kong Construction Industry (Doctoral Dissertation). Hong Kong Polytechnic University, Hong Kong., China.

Underwood, J. \& Ayoade, O. (2015). Current Position and Associated Challenges of BIM Education in UK Higher Education.

World Economic Forum \& The Boston Consulting Group. (2018). An Action Plan to Accelerate Building Information Modeling (BIM) Adoption.

Zainon, N., Rahim, F. A. \& Salleh, H. (2011), The Information Technology Application Change Trend: Its Implications for the Construction
Industry. Journal of Surveying, Construction and Property, 2 (2011), 6 - 20.

Zakaria, Z., Ali, N. M., Haron, A. T., MarshallPonting, A. \& Zuhairi, A. H. (2013), Exploring the adoption of Building Information Modelling (BIM) in the Malaysian construction industry: A qualitative approach. International Journal of Research in Engineering and Technology, 2 (8), 384 - 395.

Zhu, J., Wu, P., Chen, M., Kim, M. J., Wang, X. \& Fang, T. (2020), Automatically processing IFC clipping representation for BIM and GIS integration at the process level. Applied Sciences (Switzerland), 10 (6), 1 - 19.

113 | This work is licensed under a Creative Commons Attribution 4.0 International License. 